\title{
Tratado dos Anjos Afogados, de Marcelo Ariel
}

\author{
Joño Luiz PeÇanha Couto \\ Universidade de São Paulo
}

á desde o final do século XX vem-se questionando sobre o que será do poema num mundo bombardeado por transformações geopolíticas e culturais: mundialização, novos arranjos políticos e econômicos e novas tecnologias. Desse combinado de influências e configurações, a linguagem e suas funções e possibilidades necessariamente sairiam também refiguradas; um rol imenso de novos suportes (sites, blogs, vídeos, MP3 etc.) para se produzir e distribuir a poesia (e o trabalho ficcional em geral) na forma escrita ou falada se apresentaria e obrigaria um poeta-escritor a lidar competentemente com tais mutações que, por sua vez, proporcionariam novas fontes e novos caminhos para a criação: um moto contínuo.

A sedimentação dessa suposta pós-modernidade e das possibilidades técnicas e tecnológicas existentes nas novas práticas da escrita, no entanto, até então malogrou, ainda não chegando com força a se espraiar na produção poética contemporânea. A poesia que se faz hoje não apenas ainda não se apropriou dos aportes do novo milênio, mas também não tem tido sucesso, na maioria das vezes, na tarefa de traduzir ou mesmo questionar esse momento de transformações culturais e, sobretudo, simbólicas.

Além disso, igualmente ainda são raros os exemplos de produtores textuais capazes de comporem obras que internamente utilizem uma linguagem apropriada para o estabelecimento de relações literárias com outras artes e suportes, além de diversas áreas do conhecimento.

Tratado dos anjos afogados, do poeta e dramaturgo santista Marcelo Ariel (1968-), é um oásis nessa névoa de impossibilidades, pois consegue traduzir algumas daquelas propostas por meio de uma plurivocidade sem amarras e de uma hibridização bastante pessoal de tentativas de um novo fazer poético. 
O volume de poemas mencionado não surpreende o leitor apenas por ser a reunião e a condensação de uma estética própria, construída ao longo de vinte anos, mas sobretudo por assinalar a promessa de uma palavra poética assertiva, sem titubeações, que se utiliza à larga de saberes dispersos nas diversas possibilidades da episteme desse início de século XXI, desde a cultura grafitada das ruas até o diálogo intelectual com outros poetas e filósofos, influências confessas e companhias poéticas desejadas.

Tratado... posiciona-se num vórtice que concentra, por um lado, certo espontaneísmo da escrita, caro sobretudo à geração da poesia marginal brasileira dos anos 1970, que teve Ana C. (Ana Cristina César) como sua resultante mais interessante, entrevisto na invasão do quase escatológico no sublime poético ("invade o poema um menininho fumando crack na esquina/dentro da vida cínica”, Ontologia \& merda, p. 54); e por outro lado acena com um trabalho de erudição mental e intelectual na construção do poema, fincado por um competente trabalho de autocrítica ("Impossível não pensar/No fracasso invisível/dos cadernos de cultura/onde o tédio de Camus/encontra o de Valéry/e ambos são dissolvidos/pelo olhar de um catador de papel/ às quatro da manhã/na portaria da USP", O soco na névoa, p. 60), e por vezes também aliando-se a um fazer poético a ajuntar elementos líricos com outros, do universo do absurdo e do fantástico, na esteira de um Herberto Helder ("No ultra-sonho/estar sendo é ter sido/onde um polvo/epiléptico feito de dois corpos/procura em vão/a luz entre carcaças/depois se transforma/num transparente e maravilhoso/pássaro cego", O amor, p. 51).

Tal multiplicidade de lugares habitados pelos poemas de Tratados dos anjos afogados acaba por deslocar a poesia de um espaço falsamente oficial, ocupado por ela quando se permite confortar-se em ser amparo para o establishment literário. No novo espaço, o poema igualmente inaugura uma forma diversa e difusa de enxergar e fazer enxergar a realidade. Assim, a mesma condensação de tendências e olhares está na reunião de dois estratos de marginalidade, dois lados estranhos ao comum, refratados pela lente de Ariel: um representado pelos traficantes Sol e Draculino ("As unidades prisionais são/um átomo do Hades.../Ali os netos dos sobreviventes de Canudos/tomam duas horas de sol cada/e transformam uma lágrima em faca", Nova cadenza dos Comandos, p. 74), e o outro, igualmente marginal à média, habitado por Celan, Kafka, Tolstói etc. Vê-se, portanto, constante contraponto entre uma cuidadosa construção 
poética e a vitalidade de uma escrita "sem papas na língua". Dessa reunião, emerge a erudição da tradição literária dialogando com o hiph-hop inflamado das gangues e dos comandos, estes dois últimos versões finais de uma desigualdade renitente que acaba por banalizar uma violência já historicamente sedimentada ("e o desejo/por carnificinas/tão banais/que equivalem/a ouvir/no cinema/ um celular tocando/no meio do filme", O soco na névoa, p. 61).

Falando em tradição: acostumado a rechear seus poemas de referências - suas companhias e suas homenagens, como as que faz a Baudelaire, Rimbaud, Klee e Drummond - o poeta as utiliza como ponto de apoio para uma sofisticada e surpreendente operação de construção do pacto poético. Exemplo disso quando traz Dante e sua Beatriz para o inferno de Vila Socó : "bebê de oito meses é defumado/enquanto Beatriz/agora entende o poema derradeiro" (Caranguejos aplaudem Nagasaki, p.23). O Inferno (da tradição literária) e o inferno (da crueza das ruas e do descuido oficial) agora estão juntos pelas mãos do poeta.

Logo no primeiro poema, $O$ espantalho, nos é ofertado um discurso muito distante daquele vazio estético encontrado em grande parte das tentativas de se fazer poesia nesse novíssimo milênio. A crueldade da metonímia surge no poema como que antecipando o resto do livro ("no meio do lixão/visão do alto/uma calça e uma camisa/São a/evocação do corpo/de um homem/sem sapatos/suas mãos/dois urubus rasgando um saco./sua cabeça/um rato”, p. 21). Aquilo que se quer dizer está impresso sem rodeios na materialidade do papel, onde poesia e vida se mesclam; lirismo desabrido se compõe com versos que se aproximam da prosa; vê-se lado a lado, sem tentativas vãs de uma síntese, a tradição e suas rupturas, confusão de domínios na expressão do que emerge como insólito: silhuetas de sub-vivos tropeçando em si mesmos, fantasmas, anjos sem asas e sem céu que sirva de abrigo. No açougue do ser, que emerge da névoa, da incapacidade de enxergar o outro diferente, o espantalho é a própria humanidade ("infernais explosões de carne morta embrulhadas em perguntas", p. 159) confundida e confusa, mesclando-se ao que ela expurga de si mesma: seu lixo e seu fim. Sua "humanidade" jaz dilacerada por predadores com os quais muitas vezes metaforicamente se assemelha.

Pensando no título da obra, os fotogramas de uma catástrofe se formam como que num purzle de crueldades: os anjos, o lodo, o aviso, um descuido, a tragédia, o incêndio, o desespero, a morte, o amanhecer distópico. O jovem que, num fevereiro de 1984, viu tudo isso agora nos faz pensar a respeito da 
questão da originação de um poeta, do transbordamento de uma necessidade ou de uma vocação para a escrita. Afinal, que motivações há para que alguém se torne poeta? Ou: é necessária alguma motivação? Se for, se realmente existir a necessidade de um memorial de perdas ou ganhos que torne alguém instado por um movimento desconhecido e inesperado a escrever, esse poeta santista seria sua clara confirmação, uma vez que se vê, límpida e trágica, a silhueta de Vila Socó atrás de cada verso, em cada anjo eleito ou perdido, em cada morte inserida no poema e no diálogo constante que o poeta faz com a "indesejada das gentes". Por vezes, em sua luta por compreensão do mundo, o poeta toma a realidade ("mera quimera/que o sonho incinera", p. 118), de tão absurda, como um pesadelo, um "anti-sonho" ("Sonho que sou um peixe de gelo/e lentamente me transformo num peixe de fogo,/Sonho que acordo e não me lembro onde deixei meu corpo,/Sonho que acordo e não me lembro de ter acordado... e as/duas sensações/são a mesma", O soco na névoa, p. 68).

A convivência de longo tempo do poeta com a morte, com "os pequenos incêndios cotidianos a que ainda assisto", fez com que a finitude estivesse inapelavelmente encravada no cerne de cada poema, afirmando a própria vida: "Antes colado a um agora/devorado na carne/por esse lento cardume/ de piranhas invisíveis/guiado pelos ponteiros" (No espelho, p. 137). Daí se deduz que a morte, assim como a vida, é apenas um dos lados do espelho ("O espelho/Não é uma fronteira/Cercada de luz/Se parece mais com o que divisa um lago", O reflexo de K.R., p. 29), tanto que os mortos de Vila Socó vivem em Ariel e em sua obra; e Ariel, vivo, caminha como Lázaro, meio vivo ("Na morte/o núcleo do silêncio/onde logo estaremos/uma vez dentro/sim é não/e não é nada/os de fora dizem/morremos/não podem ouvir nossa $\mathrm{vOz} /$ num sussurro dizendo/tudo está em nós”, Na morte, p. 141).

Assim, coerente com o mundo a partir do qual forjou-se como poeta, Marcelo Ariel é quase sempre amargo e arde na língua como a chuva ácida arde na carne. Contudo, nas poucas vezes em que ele permite que se entreveja, o lirismo surge refigurado: "Será sempre/este esquecido alfabeto/cujas letras são nuvens,/tocando suavemente o nosso olhar/e os lagos?/O que diz a água/ dentro dela antes de tocar a terra?/O que sussurra no ouvido da água o ar?/ Como decifrar essa chuva imóvel para os mortos?/E essa outra chuva que escreve vida no ar?" (Enigma, p. 49). 
Os poemas do livro fazem concordar com Leyla Perrone-Moisés e sua "Inútil poesia": de tão massacrante, a realidade se sobrepõe à força renovadora, mas indireta, de esguelha, do poema ("O que pode um poema contra os fatos?", A resposta, p. 169). O fazer poético, assim, não se arvoraria a produzir efeito algum sobre a realidade - o poema encara sua impotência, e é com ela e por ela que se faz poema ("poemas são a merda da alma/E o tempo é uma lenta bala perdida, me diz o silêncio do/Menino", Ontologia \& merda, p. 54). Semelhante à poesia e a seu efeito sobre um mundo (museu dos vivos, shopping-abismo) em que a literatura tornou-se exercício de nivelamento às "marcas-literárias", de imitação daquilo que já foi dito, de apenas simulação do autêntico - o ato da escrita ou o desejo de publicar o escrito equivale a "acender um fósforo molhado". Inútil poesia? A resposta: que não a caracterizemos como inútil, mas necessariamente como inesperada. Assim como Berardinelli, para quem a tentativa de inserir o poema num quadrado (espaço delimitado) analítico é tão útil como se instalar um espelho no escuro, Ariel não aceita esquadrinhamentos ou conceituações para seu fazer poético e tem em sua proposta estética clara a saída para compreender o incompreensível: o poema como lente para um diálogo contínuo com um real que assoma como açougue ("um açougue chamado corpo") ontológico, metafísico, incêndio que não cessa e se reproduz em vários incêndios cotidianos, morte que consome vida, silêncio que escuta silêncios e consegue apenas entrever a densa névoa. A incompreensão do açougue cotidiano é a constante.

Assim, a saída de compreensão para o aparentemente indecifrável Titanic world está no poema e na sua tentativa última de decodificação do mundo: o silêncio. $\mathrm{O}$ mesmo silêncio que ecoou naquela manhã seguinte, um sábado de Carnaval de 1984, distante e orwelliano, quando um jovem assustado apenas se calava, pois o silêncio e as cinzas eram o resumo daquilo que restava. No silêncio inesperadamente pode-se acomodar, quem sabe, um amor-antídoto, como algo sempre avesso a sínteses ou simplificações, já escrito em algum inútil poema: "O amor é o silêncio/sonhando,/um silêncio tocando/o corpo/de outro silêncio" (Canção do sonho, p. 178). 


\section{Referências Bibliográficas}

ARIEL, Marcelo. Tratado dos anjos afogados. Caraguatatuba: Letra Selvagem, 2008. BERARDINELLI, Alfonso. Da poesia à prosa. Org. Maria Betânia Amoroso. Trad. Maurício Santana Dias. São Paulo: Cosac Naify, 2007.

PERRONE-MOISÉS, Leyla. Inútil poesia e outros ensaios breves. São Paulo: Companhia das Letras, 2000. 